\title{
Prevalence and trends of transfusion transmissible infections among blood donors in the State of Qatar, 2013-2017
}

\author{
${\text { Mohamed Aabdien }{ }^{1 *} \text { (D), Nagah Selim,3 }}^{2,3}$, Sayed Himatt ${ }^{4}$, Saloua Hmissi ${ }^{5}$, Zeyd Merenkov ${ }^{5}$, Noora AlKubaisi ${ }^{2}$, \\ Manar E. Abdel-Rahman ${ }^{6}$, Abdelatif Abdelmola7, Shadi Khelfa ${ }^{7}$, Elmoubasher Farag ${ }^{4}$, Hamad E. Al-Romaihi ${ }^{4}$, \\ Mohamed Al-Thani ${ }^{4}$, Moutaz Derbala ${ }^{7}$ and Saad Al-Kaabi ${ }^{7}$
}

\begin{abstract}
Background: Millions of lives around the world are being saved annually through blood transfusion. However, blood transfusion is among the essential vehicles for transmitting infections. The overall prevalence of Transfusion Transmissible Infections among blood donors differs around the world, reflecting the variation in the prevalence of these infections. This study aims to assess the prevalence and trends of Transfusion Transmissible Infections among blood donors in Qatar.

Methods: This is a cross-sectional study utilizing donation records of 5 years from January 2013 to December 2017. We included in the study results for all screening and confirmatory tests for Hepatitis B Virus, Hepatitis C Virus, Human T-lymphotropic Virus-I/II, Syphilis and Malaria.

Results: Among the 190,509 donations received at the donation centre during the study period, about $91 \%$ of donations were received from males and $9 \%$ from females. The overall positivity rate for all tests was 1.87, 2.23, 1.78, 2.31, 2.67\% for the years 2013 through 2017, with an increasing yearly trend by 6\% each year. The overall positivity rates for Hepatitis C Virus, Human T-lymphotropic Virus-I/II, Hepatitis B Virus, Syphilis and Malaria (2013-2017) were $0.60,0.18,0.30,0.43$ and $0.20 \%$, respectively.

Conclusion: The overall positivity rate of all tests combined for the Transfusion Transmissible Infections demonstrated a gradually increasing trend from 2013 to 2017. However, the trend for each infection (Hepatitis C Virus, Hepatitis B Virus, Syphilis and Malaria) was fluctuating except for Human T-lymphotropic Virus-1/II, which was increasing. Supporting the development of effective prevention and control strategies requires further comprehensive investigations for better estimation of the burden of these infections.
\end{abstract}

Keywords: Blood Donors, Transfusion, Hepatitis B virus, Hepatitis C virus, Human T-Lymphotropic virus, Syphilis, Malaria, Qatar

\footnotetext{
*Correspondence: MAabdien1@hamad.qa; Aabdien_Mohamed@outlook.com ${ }^{1}$ Community Medicine Training Program- Medical Education, Hamad Medical Corporation, P.O. Box 3050, Doha, State of Qatar

Full list of author information is available at the end of the article
}

(c) The Author(s). 2020 Open Access This article is licensed under a Creative Commons Attribution 4.0 International License, which permits use, sharing, adaptation, distribution and reproduction in any medium or format, as long as you give appropriate credit to the original author(s) and the source, provide a link to the Creative Commons licence, and indicate if changes were made. The images or other third party material in this article are included in the article's Creative Commons licence, unless indicated otherwise in a credit line to the material. If material is not included in the article's Creative Commons licence and your intended use is not permitted by statutory regulation or exceeds the permitted use, you will need to obtain permission directly from the copyright holder. To view a copy of this licence, visit http://creativecommons.org/licenses/by/4.0/ The Creative Commons Public Domain Dedication waiver (http://creativecommons.org/publicdomain/zero/1.0/) applies to the data made available in this article, unless otherwise stated in a credit line to the data. 


\section{Background}

Blood transfusion is a life-saving procedure that saves millions of lives every year around the world, it can be transfused as whole blood for one patient or may be manufactured into blood-derived products to be provided for more than one patient. However, it is known that blood transfusion can be associated with risks of transmitting certain infections $[1,2]$.

These infections are known as Transfusion Transmissible Infections (TTIs), which defined as any infection that can be transmitted from person to person through parenteral administration of blood or any blood products. Thus, different outcomes may follow unsafe transfusion, as it can cause an acute clinical sickness; it can persist in the receiver as a carrier or cause asymptomatic infection [3].

These infections include viral, bacterial, parasites and prions. The most prominent among these are, Human Immunodeficiency Virus (HIV), Hepatitis B Virus (HBV) and Hepatitis C Virus (HCV), due to their high prevalence rates. Other agents are Human T-cell Lymphotropic Virus (HTLV-I/II), Cytomegalovirus (CMV), Parvovirus B19, West Nile Virus (WNV) and Dengue Viruses, Trypanosomiasis, Malaria and Transmissible Spongiform Encephalopathy (TSE) [4].

The prevalence of TTIs among blood donations varies between high and low-income countries. It was reported that the prevalence of HIV, HBV, HCV and Syphilis in high-income countries are 0.003, 0.03, 0.02 and 0.05\%, respectively. While in low-income countries, the prevalence of these infections is higher; 1.08, 3.70, 1.03 and $0.90 \%$, respectively. These differences reflect the variation in the prevalence of these infections among the populations of these countries [5]. These variations are also observed between the World Health Organization (WHO) regions. As African and Pacific regions are the highest in $\mathrm{HBV}$ prevalence, Eastern Mediterranean region is the highest for HCV prevalence, Sub-Saharan Africa is the highest for malaria, and scattered foci in southwestern Japan, Colombia and intertropical Africa are endemic for HTLV-1 [6-8].

Many global efforts are provided to ensure the safety of the whole blood transfusion process. These efforts include providing recommendations and guidelines to establish a national blood screening and surveillance system for the entire transfusion chain, i.e. haemovigilance system. Moreover, efforts are also provided for the establishment of the Global Database on Blood Safety (GDBS), aiming to improve transfusion services globally $[9,10]$.

In Qatar, Expatriates comprised a high proportion of Qatar's population, coming from all over the world, with diverse and unique epidemiological characteristics for each region. Enormous efforts aimed at protecting the health of the population and prevention the spread of infectious diseases from newcomers. Among these efforts is the law that mandates all newcomers wishing to work and live in Qatar to undergo a medical exam and infectious diseases screening to be able to receive a residence permit. Furthermore, specific job categories, including health care personnel and food industry workers, are required to undergo annual medical check-ups.

The Blood Donor Center at Hamad Medical Corporation (HMC) is responsible for the provision of safe blood supply through the efforts provided to ensure that donated blood is free from infections. However, few local epidemiological studies are assessing the prevalence and trends of transfusion-transmitted infections among blood donors, comprehensively. Hence, conducting this study to assess transfusion transmissible infections among blood donors can provide a better understanding of the epidemiology of these infections, which can support strategies development to evaluate safe blood supply measures, in addition to the preventive and control measures that are needed to manage the burden of these infections in the community. Therefore, the study aims to assess the prevalence and the trends of the transfusion transmissible infections among blood donors during the period 2013-2017, in Blood Donor Center at HMC in the State of Qatar.

\section{Methods \\ Study setting}

The Division of Transfusion Medicine includes the Blood Bank Section \& Donor Unit. The Transfusion Division is the only provider of blood and blood components in the State of Qatar. Its main function is to assure the availability of safe blood whenever needed. The centre follows international recommendations for the provision of safe, efficacious blood products and transfusion. In September 2017, HMC's committee for blood transfusion announced a new program for monitoring blood transfusion process in the country. The Centralized Hemovigilance Program aims to improve the quality of the blood transfusion chain, with the main focus on safety.

The program was initially implemented at HMC and was introduced across all healthcare facilities around the country, that collect, use or store blood and its products. All donated unit samples undergo screening tests prior transfusion for the following infectious, through following methods: Chemiluminescent Microparticle Immunoassay (CMIA) by (ARCHITECT, Abbott laboratories) for detecting HIV Ag/Ab, HBsAg. In addition to antibodies for HTLV-I/II, Syphilis TP, HCV, HBsAg and anti-HBc. Confirmatory tests are performed through Line Immuno Assay (LIA) by (FUJIREBIO, Europe N.V.) as a confirmatory test for the presence of these antibodies. Moreover, (ARCHITECT, Abbott laboratories) Malaria Ag P.f/Pan 
and Enzyme-linked Immunosorbent Assay (ELISA) by (NOVA TEC IMMUNOIAGNOSTICA, GmpH) are used for determination of Plasmodium antigens and antibodies, respectively.

\section{Data collection}

This is a cross-sectional study, conducted using data of all blood donations received in the period between January 2013 and December 2017 at Blood Donor Center in HMC. All data included in the study were retrieved from the records anonymously with no identifications of the donors. An extraction sheet was used, and data were provided only as frequencies of positive results for each screening test, in addition to basic demographics including age, gender and nationality of all donors. Tests included in this study were: HBsAg, HBcAb, HBV NAT, HCV Ab, INNO-LIA HCV, HCV NAT, HTLV-I/II Ab, INNO-LIA HTLV-I, Syphilis Ab and INNO-LIA Syphilis, in addition to Malaria $\mathrm{Ab}$ and $\mathrm{Ag}$ tests. Data for HIV were not included due to its sensitivity, complexity, need for careful handling and unique address with a specific and comprehensive approach.

\section{Data Analysis}

Data were extracted from the records and entered to Microsoft excel. Frequencies and percentages were used for the description of blood donors by gender, age groups and nationality. Furthermore, the analysis was conducted to assess the positivity rate of the transfusion transmissible infections distribution by age groups, gender, and nationality (Qataris and Non-Qataris). Infections positivity rates were calculated for each year to identify trends throughout the 5 years. Categorical variables were compared using the $\chi^{2}$ test. Test for trend $p$ value was obtained using multivariable Poisson regression with robust variance modelling the rate of positive tests to year (as a continuous variable) adjusting for age and using the proportion of donors in the population as an offset. $P$-values less than 0.05 were considered statistically significant, and Stata/ SE version 15 was used to conduct the analysis.

\section{Results}

A total of 190,509 donations were received at Blood Donor Centre in HMC in the period between January 2013 and December 2017. About 91\% of the donations were received from males and $9 \%$ from females (Table 1). Moreover, donors of the age group 31-40 years were the highest to donate blood, with a percentage of $38.6 \%$ of the total donations during the study period (Table 1). Qataris were among the top six nationalities to donate blood in all years of the study (Fig. 1).

The positivity rates for all the tests combined (i.e. screening and confirmatory) were: $1.87,2.23,1.78,2.31$, $2.67 \%$ for the years 2013, 2014, 2015, 2016 and 2017, respectively (Fig. 2). Multivariable Poisson regression analysis showed that compared to the year 2013, the ageadjusted incidence rate ratio of positivity for years 2014, 2015, 2016 and 2017 were 1.24, 1.02, 1.24 and 1.32, respectively. The average age-adjusted rate of positives tests significantly increased by $6 \%$ each year $(P<0.001)$.

Furthermore, the positivity rates for tests combined were compared between male and female donors. Results showed that the rates were more among male donors in 2013 through 2015, which was significant only for 2013 and $2014(P<0.001)$. However, in 2016, the rates were significantly higher among females $(P<$ $0.001)$, but the difference was again higher among male donors $(P=0.056)$ in 2017 (Fig. 3).

Assessing the positivity rates among age groups showed that the rates were higher among young donors, except for the years 2013 and 2014, in which the rates

Table 1 Demographic characteristics of blood donors in Blood Donor Center at HMC in the period 20132017

\begin{tabular}{|c|c|c|c|c|c|c|}
\hline Year & 2013 & 2014 & 2015 & 2016 & 2017 & Total \\
\hline \multirow[t]{2}{*}{ Total Donations } & 26,153 & 38,577 & 42,528 & 40,865 & 42,386 & 190,509 \\
\hline & N (\%) & N (\%) & N (\%) & N (\%) & N (\%) & N (\%) \\
\hline \multicolumn{7}{|l|}{ Gender } \\
\hline Male & $24,140(92.3)$ & $34,961(90.6)$ & $38,531(90.6)$ & $37,028(90.6)$ & $38,577(91.0)$ & $173,237(90.9)$ \\
\hline Female & $2013(7.7)$ & $3616(9.4)$ & $3997(9.4)$ & 3837 (9.4) & $3809(9.0)$ & $17,272(9.1)$ \\
\hline \multicolumn{7}{|l|}{ Age Group } \\
\hline$\leq 20$ & $770(2.9)$ & $1276(3.3)$ & $1194(2.8)$ & $1357(3.3)$ & $915(2.2)$ & $5512(2.9)$ \\
\hline $21-30$ & 9035 (34.5) & $13,341(34.6)$ & $14,598(34.3)$ & 13,847 (33.9) & $13,131(31.0)$ & $63,952(33.6)$ \\
\hline $31-40$ & $10,044(38.4)$ & $14,609(37.9)$ & $16,112(37.9)$ & 15,706 (38.4) & $16,974(40.0)$ & 73,445 (38.6) \\
\hline $41-50$ & 4831 (18.5) & 6977 (18.1) & 7920 (18.6) & 7424 (18.2) & 8381 (19.8) & $35,533(18.7)$ \\
\hline $51-60$ & $1337(5.1)$ & $2142(5.6)$ & $2429(5.7)$ & $2264(5.5)$ & $2644(6.2)$ & $10,816(5.7)$ \\
\hline$>60$ & $136(0.5)$ & $232(0.6)$ & $275(0.6)$ & $267(0.7)$ & $341(0.8)$ & $1251(0.7)$ \\
\hline
\end{tabular}




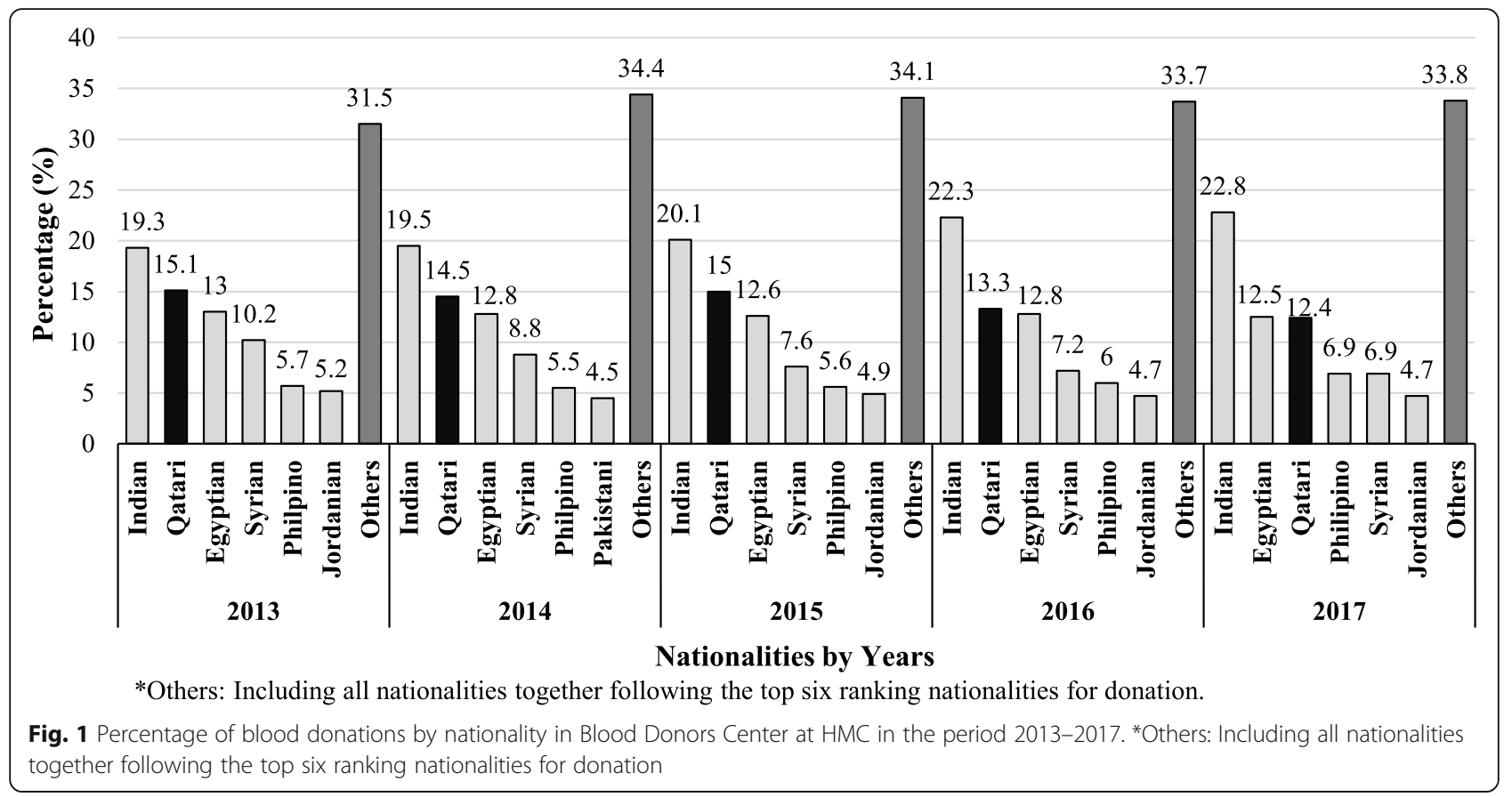

were higher in older age groups $(P<0.001)$, (Table 2$)$. Moreover, when the rates were assessed according to nationality throughout the years, it was found that these rates were higher in Non-Qataris compared to Qataris throughout all the study period $(P<0.001)$, (Fig. 4).

Furthermore, positivity rates of the screening tests were found to be fluctuating over time, for HBV $(P=0.256)$, Malaria $(P=0.523)$, Syphilis $(P=0.868)$ and HCV $(P=0.067)$. However, trends were increasing for HTLV I/II from 0.08 to $0.23\left(X^{2}=17.563\right.$ and $\left.P<0.001\right)$ as shown in (Table 3$)$.

\section{Discussion}

Even though blood transfusion saves millions of lives every year, unsafe blood remains a threat to the spread of infections. Moreover, it's also important to address the fact that safe blood is considered a universal right, and it should not cause any harm. Thus, it should be fully screened and ensured not be contaminated by any transmissible infection [11].

Blood donation centres are among valuable sources of data, as the prevalence of transfusion transmissible infections among blood donors differs throughout the world, and it can indirectly reflect the burden variations among these populations. This is because blood donors are usually representing the healthy members of the community so that it can have its inferences on the general population. Currently, the number of registered donors at Blood Donor Center in HMC had increased noticeably

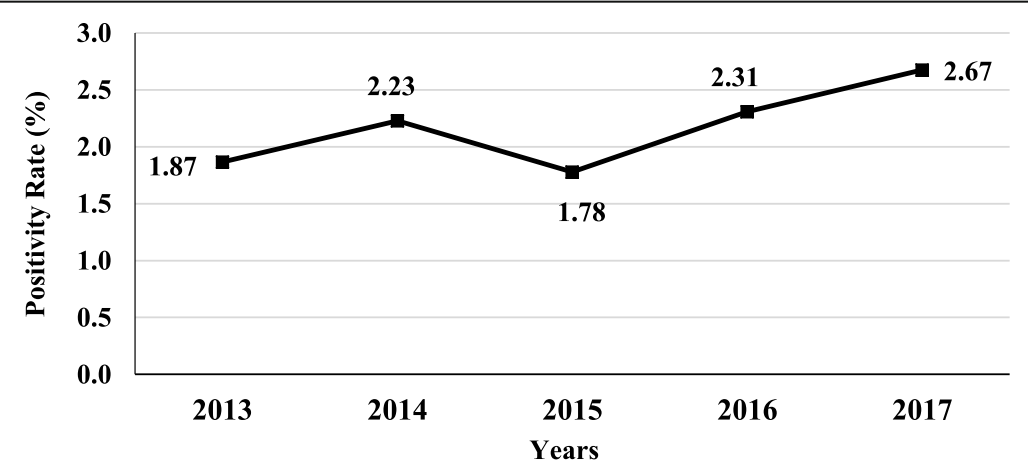

Fig. 2 Temporal trend of total TTls prevalence using combined serological and NAT screening (HBsAg, HBCAb, HBV NAT, HCV Ab, INNO-LIA HCV, HCV NAT, HTLV-I/II Ab, INNO-LIA HTLV-I, Syphilis Ab and INNO-LIA Syphilis, in addition to Malaria Ab and Ag tests) among blood donors in blood donors centre at HMC in the period 2013-2017 


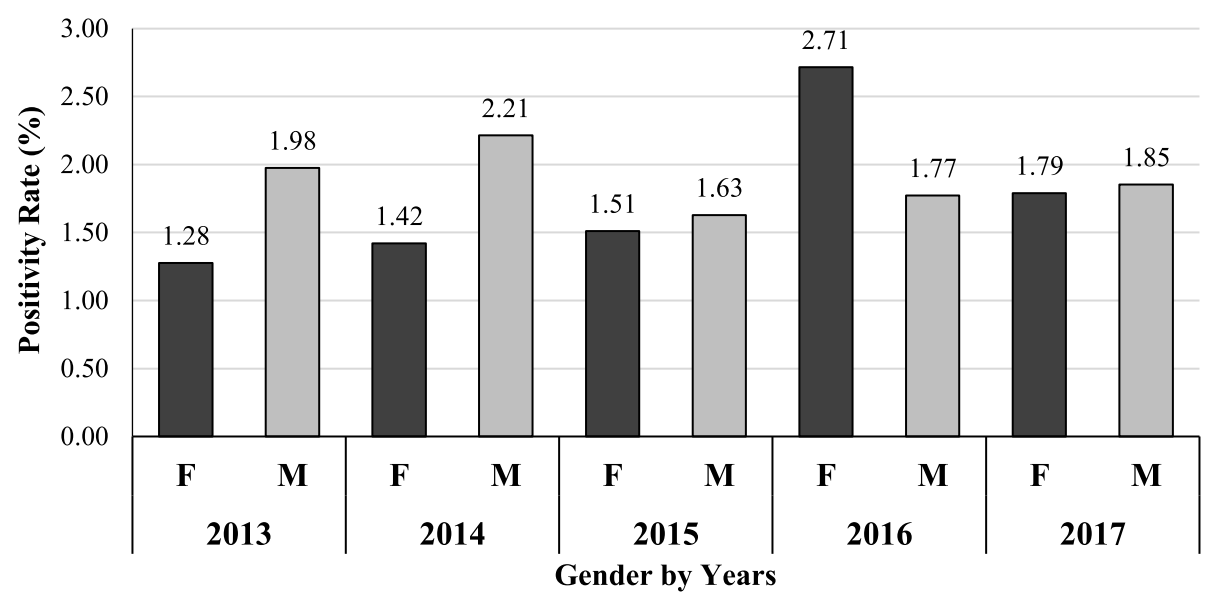

Fig. 3 Gender distribution of positivity rate for combined serological and NAT screening (HBsAg, HBCAb, HBV NAT, HCV Ab, INNO-LIA HCV, HCV NAT, HTLV-I/II Ab, INNO-LIA HTLV-I, Syphilis Ab and INNO-LIA Syphilis, in addition to Malaria Ab and Ag tests) of blood donors in Blood Donors Center at HMC in the period 2013-2017

as a result of the continuous promotion, motivation, guidance, and education efforts about the importance of blood donation, which led to the overall rise in the general public awareness.

In this study, the predominance of blood donations was by males, which was consistent with several studies $[12,13]$. Literature showed that women contribute less to blood donations than men due to many factors, including physiological factors such as menstruation, lactation and pregnancy [14]. However, some studies showed that this difference between gender is much less $[15,16]$.

The predominance of males' contribution to blood donations was also observed in regards transfusion transmissible infections positivity rates, as this study showed a consistent predominance throughout most of the years, in which rates were higher in male donors. These were similar to the findings from studies in the region [17-20].

In general, the younger population seems to contribute more to blood donation, as it was shown in several studies, in which most donors were less than 30 years in age $[12,21,22]$. However, in this study, most of the blood

Table 2 Age distribution of positivity rate (\%) for TTls combined tests of blood donors in Blood Donors Center at HMC, 20132017

\begin{tabular}{llllllll}
\hline Age Groups & $\leq 20$ & $21-30$ & $31-40$ & $41-50$ & $51-60$ & $>60$ & P-value \\
\hline $\mathbf{2 0 1 3}$ & 1.53 & 1.61 & 2.06 & 2.36 & 2.23 & 1.39 & $P<0.001$ \\
$\mathbf{2 0 1 4}$ & 2.42 & 1.87 & 2.28 & 2.46 & 2.32 & 3.10 & \\
$\mathbf{2 0 1 5}$ & 2.48 & 1.47 & 1.59 & 1.84 & 1.63 & 2.32 & \\
$\mathbf{2 0 1 6}$ & 4.66 & 1.73 & 1.71 & 1.84 & 1.83 & 1.45 & \\
$\mathbf{2 0 1 7}$ & 6.35 & 1.72 & 1.80 & 1.86 & 1.54 & 3.02 & \\
\hline
\end{tabular}

Combined Tests: (HBsAg, HBcAb, HBV NAT, HCV Ab, INNO-LIA HCV, HCV NAT, HTLV-I/II Ab, INNO-LIA HTLV-I, Syphilis Ab and INNO-LIA Syphilis, in addition to Malaria $\mathrm{Ab}$ and $\mathrm{Ag}$ tests) donors found to be aged 31-40 years old. Additionally, positivity rates of infections were found to be more in the younger population, which was also found in other studies conducted in countries from different regions [21-23].

In literature, it has been discussed that young males are more to be involved in risky behaviours than females and older age groups. Moreover, results from several studies showed that some donors are involved in risky behaviour activities, yet they contribute to blood donation. The reason is that they use it to check if they were infected with any of the infections that can be related to their risky behaviours [24-26].

In this study, the positivity rates of the combined tests, including serological and NAT tests, were assessed throughout the years 2013 to 2017. By assessing these rates during this period, we were able to identify the trend for these infections, which found to be an increasing trend, after adjusting to age and the total population. Despite this increasing trend, yet, the rates were less than what was found in countries from different regions, such as Saudi Arabia, Egypt, India and Nigeria [27-30].

Moreover, the positivity rates were also assessed for selected tests throughout the study period. The results showed a fluctuating trend for HBsAg, between 0.34 in 2013 and 0.29 in 2017. These rates are less than what has been found in studies from countries in the region including Saudi Arabia, Kuwait, Jordan and Egypt [31], which can be attributed to the effective prevention and control strategies including vaccination programs [32].

The rates for $\mathrm{HCV} \mathrm{Ab}$ showed a changing trend between 0.58 in 2013 and 0.70 in 2017. However, these rates are less than the reported from Egypt and Saudi Arabia [33], which can be attributed to the high prevalence of the disease among the general population and 


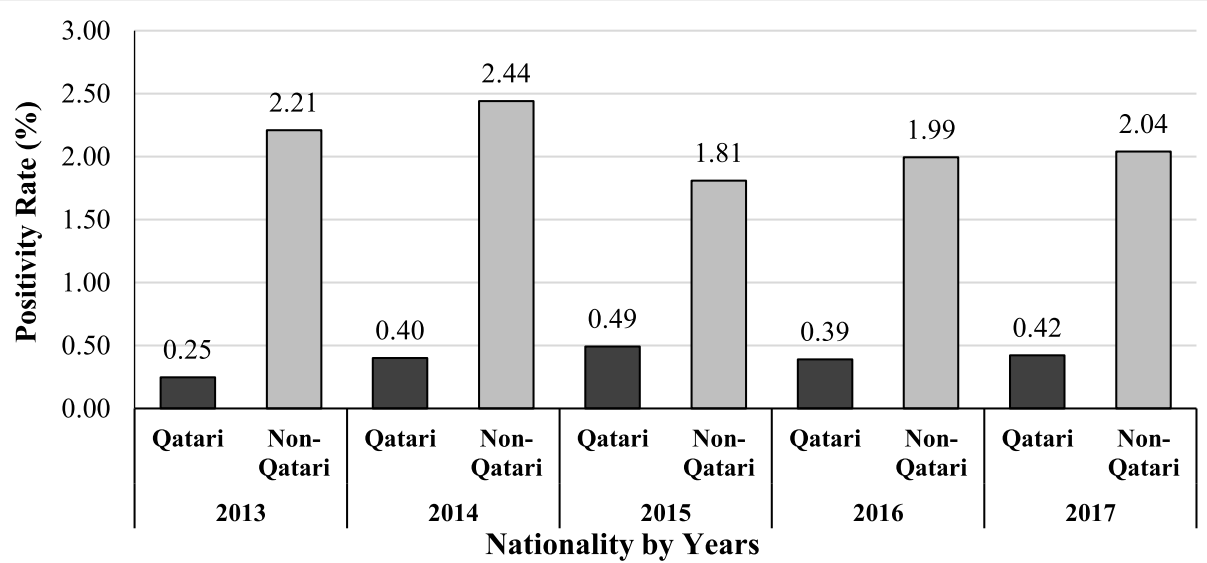

Fig. 4 Positivity rate (\%) for TTIs tests combined: (HBsAg, HBCAb, HBV NAT, HCV Ab, INNO-LIA HCV, HCV NAT, HTLV-I/II Ab, INNO-LIA HTLV-I, Syphilis Ab and INNO-LIA Syphilis, Malaria Ab and Ag tests) of blood donors (Qatari Vs Non-Qatari) in Blood Donors Center at HMC in the period 2013-2017

the migration from these countries to other countries with lower prevalence [34]. This was consistent with findings from our study, as the rates were higher among the Non-Qataris throughout the years. However, the rates were higher than what was reported from other countries in the same region (i.e. middle east region), like Iran and Turkey [33].

Furthermore, screening for HTLV is also among the recommended screening for transfusion, and this includes two viruses: I and II that differs in their geographical distribution and clinical disease association. HTLV is endemic in some parts of the world, and in some regions, the prevalence of the virus is very low, as the situation here in Qatar.

The cost-effectiveness of the universal screening strategies for HTLV has been argued. This was especially for the screening implementation by high-income countries with a low prevalence of the infection [35, 36]. Qatar is among these countries. However, it is a destination for working force from all around the world, including areas endemic with the virus. Therefore, HTLV is among the screening requirements for blood safety in the country. The positivity rate for HTLV I/II Ab in 2017 found to

Table 3 Temporal trends positivity rate (\%) for screening among blood donors in Blood Donors Center at HMC in the period 2013-2017

\begin{tabular}{llllllll}
\hline Year & 2013 & 2014 & 2015 & 2016 & 2017 & Overall & P-value \\
\hline HCV Ab & 0.58 & 0.58 & 0.56 & 0.60 & 0.70 & 0.60 & 0.067 \\
HTLV I/II Ab & 0.08 & 0.16 & 0.20 & 0.22 & 0.23 & 0.18 & $<0.001$ \\
Syphilis Ab & 0.48 & 0.49 & 0.35 & 0.41 & 0.45 & 0.43 & 0.868 \\
HBsAg & 0.34 & 0.28 & 0.31 & 0.26 & 0.29 & 0.30 & 0.256 \\
Malaria Ag & 0.14 & 0.24 & 0.42 & 0.10 & 0.10 & 0.20 & 0.523 \\
\hline
\end{tabular}

Screening Tests: (HCV Ab, HBsAg, HTLV I/II Ab, Syphilis Ab and Malaria Ag) be 0.23 , which represents an increasing trend from 0.08 in 2103. Further analysis for the findings showed that the positivity rates were more in Non-Qataris than Qataris for the screening test, but zero positivity among Qataris for the confirmatory test (i.e. INNO-LIA), which is consistent with epidemiological distribution of the disease, considering Qatar as low prevalence area for HTLV [7].

Donors can threaten blood safety with risky behaviour as they may potentially acquire syphilis, among other infections. In this study, the positivity rates for Syphilis $\mathrm{Ab}$ among donors throughout the years showed a fluctuating trend that reported to be 0.48 in 2013 and to be 0.45 in 2017, and these rates were higher in Non-Qatari throughout the years. Yet, these rates were less than what was found in studies in neighbouring countries, such as Saudi Arabia [12, 37]. Moreover, it's important to consider the fact that a specific assay has been used to screen for syphilis (i.e. Treponema pallidum Ab), which leads to identifying whoever has been infected with syphilis, whether it is a recent or past infection, and whether it was treated or not, which may result in overestimation of the disease burden [35].

Another serious infectious agent that remains to risks blood safety is transfusion-associated malaria. The country is free from local transmission of malaria, and all the reported cases were imported from abroad, through migrants and travellers from endemic countries. Findings from our study are consistent with the situation among the general population, as the rates of positivity for Malaria $\mathrm{Ag}$ were found to be higher among Non-Qataris throughout the years. Moreover, assessing these rates throughout the year revealed a fluctuating trend. Additionally, the overall positivity rate to the regional countries showed similar rate to Saudi Arabia, but higher than the United Emirates and less than Pakistan [38, 39]. 
Finally, it is essential to highlight the fact that the variance in the prevalence of the transfusion transmissible infections among blood donors from different countries can be a reflection of an actual variance of the prevalence in these countries, in addition to the different methods used to test for these infections which can result in different estimations [40, 41].

In summary, the overall positivity rate of transfusion transmissible infections among blood donors was assessed through combined serological in addition to NAT tests, and results revealed a gradually increasing trend throughout the years, with $6 \%$ increase for each year. However, this study also revealed fluctuating trends for $\mathrm{HBV}, \mathrm{HCV}$, Syphilis and Malaria. In addition to the increasing trend for HTLV. Further analysis revealed that rates were higher among Non-Qataris throughout the years.

Despite the important study findings, some limitations are worth to be mentioned. Among which is the fact that this is a retrospective study conducted by utilizing records in the blood donor centre. The study was limited to the available data in these records only, which included tabulated results of the screening tests by basic demographics (i.e. age, gender, nationality). Population data was not available for all basic demographics' categories, thus limiting some of the analysis that accounts for populations changes. Moreover, the study would have benefited from a longer period exceeding the current period from 2013 to 2017. Another limitation is not including data about HIV, due to the sensitivity and the complexity of these data. Finally, it was not possible to assess the outcome of donors with positive results for any of the infections, as the donation records are not connected with the medical records.

\section{Conclusion}

In spite of the previously discussed limitations, this study still provides important findings that contribute to a better understanding of TTIs epidemiology. Up to our knowledge, this is the first study to assess the prevalence and trends of TTIs, including HBV, HCV, HTLV, Syphilis and Malaria among blood donors in Qatar. Further investigations are needed to assess the distribution and determinants of these infections in the community to support the development of effective prevention and control strategies and to protect the community from potential risks.

\footnotetext{
Abbreviations

Anti-HBc: Antibody to Hepatitis B core antigen; CMIA: Chemiluminescent Microparticle Immunoassay; CMV: Cytomegalovirus; ELISA: Enzyme-linked Immunosorbent Assay; GDBS: Global Database on Blood Safety; HBsAg: Hepatitis B surface Antigen; HBV: Hepatitis B Virus; HCV: Hepatitis C Virus; HIV: Human Immunodeficiency Virus; HMC: Hamad Medical Corporation; HTLV-I/II: Human T-cell Lymphotropic Virus; LIA: Line Immuno Assay; TSE: Transmissible Spongiform Encephalopathy; TTls: Transfusion
}

Transmissible Infections; WHO: World Health Organization; WNV: West Nile Virus

\section{Acknowledgements}

The authors gratefully acknowledge the Blood Donation Center at HMC for their support.

\section{Authors' contributions}

Authors participated in the study design, data analysis, results' interpretation, in addition to manuscript reviewing and writing. All authors read and approved the final manuscript. MA, NS and SH contributed substantially to the conception, study design and writing the manuscript. SAH, ZM and NA participated in data acquisition, extraction and determining study variables. MEA, AA, SK and EF contributed in data analysis, and HEA, MAT, MD and SA interpreted the study outcomes and the impact on the policy development.

\section{Funding}

This study did not receive any financial support.

\section{Availability of data and materials}

The data that support the findings of this study are available from Blood Donation Center at HMC and were used under license for the current study, and so are not publicly available. Data are however available from the authors upon reasonable request and with permission of Blood Donation Center.

\section{Ethics approval and consent to participate}

This study was approved by the Institutional Review Board (IRB) at the Medical Research Center, Hamad Medical Corporation, Doha-Qatar under the protocol number MRC-01-18-374, with a decision of 'Exempt'. Prior to the data use in this study, it was anonymised and de-identified by the Blood Donation Center at Hamad Medical Corporation. The administrative permissions were granted by the Head of Lab Medicine and Pathology Department and the Medical Director of Hamad General Hospital at Hamad Medical

Corporation.

\section{Consent for publication}

N/A

\section{Competing interests}

The authors declare that they have no competing interests.

\section{Author details}

${ }^{1}$ Community Medicine Training Program- Medical Education, Hamad Medical Corporation, P.O. Box 3050, Doha, State of Qatar. ${ }^{2}$ Community Medicine Training Program- Primary Health Care Corporation, Doha, Qatar. ${ }^{3}$ Faculty of Medicine- Cairo University, Cairo, Egypt. ${ }^{4}$ Public Health Department- Ministry of Public Health, Doha, Qatar. ${ }^{5}$ Blood Donation Unit- Hamad Medical Corporation, Doha, Qatar. ${ }^{6}$ College of Health Sciences- Department of Public Health, Qatar University, Doha, Qatar. ${ }^{7}$ Gastroenterology and Hepatology Department- Hamad Medical Corporation, Doha, Qatar.

Received: 17 September 2019 Accepted: 13 August 2020

Published online: 20 August 2020

\section{References}

1. International Society of Blood Transfusion (ISBT). Global Blood Safety [Internet]. [cited 2018 Mar 5]. Available from: http://www.isbtweb.org/ working-parties/global-blood-safety/.

2. World Health Organization (WHO). Processing of donated blood [Internet] Blood transfusion safety. [cited 2018 Mar 19]. Available from: http://www. who.int/bloodsafety/processing/en/.

3. Centers for Disease Control and Prevention (CDC). Transfusion-transmitted Infections. [Internet]. 2011 [cited 2018 Mar 19]. Available from: https://www. cdc.gov/bloodsafety/tools/investigation-toolkit.html.

4. International Society of Blood Transfusion (ISBT). Transfusion Transmitted Infectious Diseases [Internet]. [cited 2018 Mar 5]. Available from: http:// www.isbtweb.org/working-parties/transfusion-transmitted-infectiousdiseases/. 
5. World Health Organization (WHO). Blood safety and availability [Internet]: WHO; 2017. [cited 2018 Mar 5]. Available from: http://www.who.int/ mediacentre/factsheets/fs279/en/.

6. World Health Organization (WHO). New hepatitis data highlight need for urgent global response [Internet]: WHO; 2017. [cited 2018 Mar 21]. Available from: http://www.who.int/mediacentre/news/releases/2017/global-hepatitisreport/en/.

7. Gessain A, Cassar O, European Centre for Disease Prevention and Control. Geographical distribution of areas with a high prevalence of HTLV-1 infection. [Internet]. Stockholm: ECDC; 2015. [cited 2019 Apr 10]. Available from: http:// bookshop.europa.eu/uri?target=EUB:NOTICE:TQ0215177:EN:HTML.

8. Ahmadpour E, Foroutan-Rad M, Majidiani H, Moghaddam SM, HatamNahavandi K, Hosseini S-A, et al. Transfusion-Transmitted Malaria: A Systematic Review and Meta-analysis. Open Forum Infect Dis. 2019;6(7): ofz283 [cited 2020 Jan 8]. Available from: https://academic.oup.com/ofid/ article/doi/10.1093/ofid/ofz283/5514070.

9. World Health Organization (WHO). Global database on blood safety [Internet]: WHO; 2018. [cited 2018 Mar 26]. Available from: http://www.who. int/bloodsafety/global_database/en/.

10. World Health Organization (WHO). A guide to establishing a national haemovigilance system [Internet]. Geneva: WHO; 2016. [cited 2018 Mar 26]. Available from: http://apps.who.int/iris/bitstream/handle/10665/250233/ 9789241549844-eng.pdf;jsessionid=1E9DF08707F3F5A5CC1AE395 88EA87E7? sequence $=1$.

11. World Health Organization (WHO). 10 facts on blood transfusion [Internet]: WHO; 2017. [cited 2018 Mar 21]. Available from: http://www.who.int/ features/factfiles/blood_transfusion/en/.

12. Sarah YAEGA, Sabry AEGAEHES, Maryam AA-S. Seropositivity of TTls among blood donors in Hail, Saudi Arabia, from 2014 to 2015. Asian Pac J Trop Dis. 2016;6(2):141-6 [cited 2018 Dec 25]. Available from: https://doi.org/10.1016/ S2222-1808(15)61000-3.

13. Alcantara JC, Alenezi FKM, Ali OHH. Seroprevalence and trends of markers of transfusion transmissible infections among blood donors: a 3-year hospital based-study. Int J Community Med Public Health. 2018;5(12):5031-5 [cited 2018 Dec 25]. Available from: https://doi.org/10.18203/2394-6040. ijcmph20184773.

14. Bani M, Giussani B. Gender differences in giving blood: a review of the literature. Blood Transfus. 2010:8(4):278-87 [cited 2019 Jan 22]. Available from: https://doi.org/10.2450/2010.0156-09.

15. Xu T, Yi Z, Luo J, Yu H, Fan Y, Lu H, et al. Prevalence and trends of transfusion-transmittable infections among blood donors in Southwest China. J Public Health, Available from. 2018; [cited 2018 Dec 25]. https://doi. org/10.1093/pubmed/fdx189.

16. Wairimu KM, Herbert K, John M. Prevalence of transfusion transmissible infections Among Blood donated at Nyeri satellite transfusion Centre in Kenya. IOSR J Pharm. 2016;6(2):20-30 Available from: http://iosrphr.org/ papers/v6i2/D0622030.pdf.

17. Negi G, Gaur DS. Trends of Transfusion Transmissible Diseases Among Blood Donors at Uttarakhand, India. Indian J Community Med. 2014;39(3):183-6 [cited 2018 Dec 26]. Available from: https://doi.org/10.4103/0970-0218. 137161.

18. Arshad A, Borhany M, Anwar N, Naseer I, Ansari R, Boota S, et al. Prevalence of transfusion transmissible infections in blood donors of Pakistan. BMC Hematol. 2016;16 [cited 2018 Mar 25]. Available from: https://doi.org/10. 1186/s12878-016-0068-2.

19. Almaiman AA. Evaluation of Blood Donors and transfusion transmitted infections and their association with $\mathrm{ABO}$ and Rh Blood groups in Unaizah Saudi Arabia: A retrospective study. Int J Med Res Health Sci. 2018;7(3):14350 Available from: https://www.ijmrhs.com/medical-research/evaluation-of blood-donors-and-transfusion-transmitted-infections-and-their-associationwith-abo-and-rh-blood-groups-in-.pdf.

20. Keshvari M, Sharafi $H$, Alavian SM, Mehrabadi $H$, Zolfaghari S. Prevalence and trends of transfusion-transmitted infections among blood donors in Tehran, Iran from 2008 to 2013. Transfus Apher Sci. 2015;53(1):38-47 [cited 2019 Mar 29]. Available from: https://doi.org/10.1016/j.transci.2015.03.003.

21. El-Hazmi MM. Prevalence of HBV, HCV, HIV-1, 2 and HTLV-I/II infections among blood donors in a teaching hospital in the Central region of Saudi Arabia. Saudi Med J. 2004;25(1):26-33 Available from: https://www.ncbi.nlm. nih.gov/pubmed/14758374

22. Farshadpour F, Taherkhani R, Tajbakhsh S, Gholizadeh Tangestani M, Hajiani G, Sharifi N, et al. Prevalence and Trends of Transfusion-Transmissible Viral
Infections among Blood Donors in South of Iran: An Eleven-Year Retrospective Study. PLoS One. 2016;11(6) [cited 2018 Dec 26]. Available from: https://doi.org/10.1371/journal.pone.0157615.

23. Ji Z-H, Li C-Y, LV Y-G, Cao W, Chen Y-Z, Chen X-P, et al. The prevalence and trends of transfusion-transmissible infectious pathogens among first-time, voluntary blood donors in Xi'an, China between 1999 and 2009. Int J Infect Dis. 2013;17(4):e259-62 [cited 2018 Mar 24]. Available from: https://doi.org/ 10.1016/j.jijid.2012.10.006.

24. de Almeida NC, McFarland W, Murphy EL, Chen S, Nogueira FAH, Mendrone A, et al. Risk factors for human immunodeficiency virus infection among blood donors in Sao Paulo, Brazil, and their relevance to current donor deferral criteria. Transfusion. 2007;47(4):608-14 Available from: https://doi. org/10.1111/j.1537-2995.2007.01161.x.

25. Nébié KY, Olinger CM, Kafando E, Dahourou H, Diallo S, Kientega Y, et al. Lack of knowledge among blood donors in Burkina Faso (West Africa); potential obstacle to transfusion security. Transfus Clin Biol. 2007;14(5):44652 Available from: https://doi.org/10.1016/j.tracli.2007.12.005.

26. Goncalez TT, Sabino EC, Murphy EL, Chen S, Chamone DAF, McFarland W. Human immunodeficiency virus test-seeking motivation in blood donors, São Paulo, Brazil. Vox Sang. 2006;90(3):170-6 Available from: https://doi.org/ 10.1111/j.1423-0410.2006.00743.x.

27. Elbjeirami W, Al-Jedani H, Arsheed N, Elnagdi N, Abou Eisha H, Abdulwahab A, et al. Prevalence and Trends of Common Transfusion Transmitted Infections Using Serological and Nucleic Acid Markers in Saudi Blood Donors. J Blood Disord Transfus. 2015;06(03) [cited 2018 Dec 26]. Available from: https://doi.org/10.4172/2155-9864.1000280.

28. Omran D, Hussein E, Nagib M. Safety of Blood Transfusion: An Egyptian Study. J Infect Dis Ther. 2014;02(01) [cited 2018 Dec 28]. Available from: http://esciencecentral.org/journals/safety-of-blood-transfusion-an-egyptianstudy-2332-0877.1000124.php?aid=22486.

29. Sharma DC, Rai S, Bharat S, lyenger S, Gupta S, Sao S, et al. Transfusion Transmissible Infections among Blood Donors at the Blood Bank of Medical College of Gwalior: A 5 Year Study. Int Blood Res Rev. 2014;2(5):235-46 [cited 2018 Dec 28]. Available from: http://www.sciencedomain.org/ abstract/4930

30. Buseri Fl, Muhibi MA, Jeremiah ZA. Sero-epidemiology of transfusiontransmissible infectious diseases among blood donors in Osogbo, southwest Nigeria. Blood Transfus. 2009;7(4):293-9 [cited 2020 Jan 14]. Available from: https://www.ncbi.nlm.nih.gov/pmc/articles/PMC2782806/.

31. Babanejad M, Izadi N, Najafi F, Alavian SM. The HBsAg Prevalence Among Blood Donors From Eastern Mediterranean and Middle Eastern Countries: A Systematic Review and Meta-Analysis. Hepat Mon. 2016;16(3) [cited 2019 Apr 8]. Available from: https://doi.org/10.5812/hepatmon.35664.

32. Al-Romaihi H, Al-Masri H, Shawky S, Al Thani M, Al Awaidy S, Janahi MA, et al. Assessment of hepatitis B immunization programme among school students in Qatar. EMHJ. 2018;24(08):736-44 [cited 2019 Apr 8]. Available from: https://doi.org/10.26719/2018.24.8.736.

33. Ghaderi-Zefrehi $H$, Sharafi $H$, Sadeghi F, Gholami-Fesharaki M, Farasat A, Jahanpeyma F, et al. Seroprevalence of Hepatitis C Virus among Blood Donors in Middle Eastern Countries: A Systematic Review and Meta-Analysis. Iran Red Crescent Med J. 2017;19(12) [cited 2019 Apr 8]. Available from: https://doi.org/10.5812/ircmj.58045.

34. Bawazir A, AlGusheri F, Jradi H, AlBalwi M, Abdel-Gader A-G. Hepatitis C virus genotypes in Saudi Arabia: a future prediction and laboratory profile. Virol J. 2017;14 [cited 2019 Apr 8]. Available from: https://doi.org/10.1186/ s12985-017-0873-7.

35. World Health Organization (WHO). Screening donated blood for transfusiontransmissible infections: recommendations. Geneva: WHO; 2010.

36. Murphy EL. Infection with human T-lymphotropic virus types-1 and -2 (HTLV-1 and -2): Implications for blood transfusion safety. Transfus Clin Biol. 2016;23(1):13-9 [cited 2018 Dec 30]. Available from: https://doi.org/10.1016/ j.tracli.2015.12.001.

37. Alaidarous M, Choudhary RK, Waly MI, Mir S, Bin Dukhyil A, Banawas SS, et al. The prevalence of transfusion-transmitted infections and nucleic acid testing among blood donors in Majmaah, Saudi Arabia. J Infect Public Health. 2018;11(5):702-6 Available from: https://doi.org/10.1016/j.jiph.2018. 04.008.

38. Saeed AA, Al Rasheed AM, Al Nasser I, Al Onaizi M, Al Kahtani S, Dubois L. Malaria Screening of Blood Donors in Saudi Arabia. Ann Saudi Med. 2002 ;22(5-6):329-332. [cited 2019 Apr 12]. Available from: https://doi.org/10. 5144/0256-4947.2002.329. 
39. World Health Organization (WHO). Global status report on blood safety and availability, 2016. Geneva: WHO; 2017. [cited 2018 Mar 15]. Available from: http://apps.who.int/iris/bitstream/10665/254987/1/9789241565431-eng.pdf.

40. Al-Sadeq DW, Taleb SA, Zaied RE, Fahad SM, Smatti MK, Rizeq BR, et al.

Hepatitis B Virus Molecular Epidemiology, Host-Virus Interaction, Coinfection, and Laboratory Diagnosis in the MENA Region: An Update. Pathogens. 2019;8(2):63 [cited 2020 Jan 15]. Available from: https://www.mdpi.com/2 076-0817/8/2/63.

41. Al-Absi ES, Al- Sadeq DW, Younis MH, Yassine HM, Abdalla OM, Mesleh AG et al. Performance evaluation of five commercial assays in assessing seroprevalence of HEV antibodies among blood donors. J Med Microbiol. 2018;67(9):1302-9 [cited 2020 Jan 15]. Available from: https://www. microbiologyresearch.org/content/journal/jmm/10.1099/jmm.0.000807.

\section{Publisher's Note}

Springer Nature remains neutral with regard to jurisdictional claims in published maps and institutional affiliations.

Ready to submit your research? Choose BMC and benefit from:

- fast, convenient online submission

- thorough peer review by experienced researchers in your field

- rapid publication on acceptance

- support for research data, including large and complex data types

- gold Open Access which fosters wider collaboration and increased citations

- maximum visibility for your research: over $100 \mathrm{M}$ website views per year

At BMC, research is always in progress.

Learn more biomedcentral.com/submissions 